\title{
Review
}

\section{A road to nowhere: The idea of progress and its critics}

\author{
Matthew W. Slaboch \\ University of Pennsylvania Press, 2018, 194pp., \\ ISBN: 978-0-8122-4980-4
}

Contemporary Political Theory (2019) 18, S243-S246. https://doi.org/10.1057/s41296018-0246-z; published online 13 August 2018

The 1995 film La Haine opens with the narrator telling the story of a man falling from a 50-story building. As he falls, he keeps reassuring himself: "So far, so good. So far, so good. So far, so good". But what's important, the narrator tells us, isn't the fall. It's the landing.

The vignette captures certain ambivalences in the ideal of progress echoed by $A$ Road to Nowhere's figures, nineteenth century pessimists who roundly rejected its political Panglossianism. Like them, it draws out the absurdity of false optimism; it suggests that we're not heading for a better day, but for a splat; and it intimates the futility in wasting what time we have before the splat convincing ourselves it isn't going to happen.

Progress is central to our political thinking, and has been for some time. It has a long and checkered history, but it's a funny kind of history because it's a funny kind of ideal, one so protean that it pops up just about anywhere you care to look. Modernity is the story of progress; the Enlightenment revels in it; Manifest Destiny indulges it. It runs through capitalism's expansion or declension, depending on who you ask, and through the rise and fall of empires. For Hegel, it serves theodicy, for Comte it's a scientific fact, and for Kant, a necessary hope. From Enlighteners to Romantics, Jacobins to Tsars, anarchists to positivists, Reagan to Obama and far beyond, few political aspirations fail to appeal to some version of it. Progress is, then, a slippery political beacon, amenable to a great many usages and contexts, for better and for worse.

It has also endured something of a beating recently, as atavistic retrenchments and visions of social degeneration have become our political currency. A Road to Nowhere is thus particularly timely, a book for the cynical era we've come to inhabit. Slaboch's wide-ranging study introduces what for most political theorists will likely be relatively unfamiliar figures, radical critics resolutely set against political optimism. Each of the book's three main chapters centers on a given thinker/context, providing an expansive and historically sensitive exposition of a

(c) 2018 Springer Nature Limited. 1470-8914 Contemporary Political Theory Vol. 18, S4, S243-S246 
subterranean political sensibility. Chapter 1 delves into Arthur Schopenhauer's "metaphysical pessimism" (19) and vituperative attacks on German idealists' historicism - Kant, Herder, Fichte, and worst of all, Hegel. Chapter 2 offers a panoramic view of Slavophiles and Westerners struggling over Russia's past, present and future, centering on Leo Tolstoy's condemnation of western materialism (by way of Alexander Herzen, Fyodor Dostoevsky, and Tsar Nicholas I). Chapter 3 turns to the height of Gilded Age optimism and Henry Adams' embittered critique of American democratic corruptions. Chapter 4 updates each context for the twentieth century, treating Oswald Spengler, Aleksandr Solzhenitsyn, and Christopher Lasch, and the book's brief conclusion hints at the argument's present-day utility, when "[f]rom Brexiteers bucking the European Union to America-firsters looking to make their country "great again"” (114), progressivism appears on its heels. Slaboch aims "to understand the conditions that give rise to historical pessimism and to assess the political implications of such pessimism" (5) so that political theorists "can learn from and appreciate critics of the idea of progress, who deserve a fairer hearing than they have received" (116).

What that lesson might be, however, is somewhat less evident, as the idea's evasiveness obscures the problem on which these thinkers converge. Progress' malleability makes for an elusive target, and pitched overly broadly, not much falls outside of it. Critiques need a common object: what makes the postcolonial one so effective, for instance, is that it shows how the European ideal of progress sustained imperial depredations over centuries (despite their far-reaching analyses of progress' complicity in a half-millennium of political domination, it's worth noting, postcolonial arguments and their cognates receive no mention). Slaboch's protagonists lack a shared concern that might reach beyond their immediate contexts and speak to one another, and to us, in generative ways. The problem of/ with progress, for each of them, is different. For Schopenhauer, it justifies an expansive state and fuels nationalism; for Tolstoy, it embodies western materialism and spiritual decay; and for Henry Adams, it conceals Washington's moral bankruptcy. Christopher Lasch decries the "vague utopianism of the French Enlightenment" (105) while endorsing a "merely hopeful" (104) sanguinity, and Brooke Adams and Oswald Spengler believe in western progress, but reject the "liberal universalist visions of progress and the political programs associated with them" (114). Schopenhauer takes it as an existential failure, an inability to squarely face up to the human condition's misery, where Solzhenitsyn sees the emaciation of mass commercialism. We're left with apples and oranges: what is the exact problem that we might cull from these thinkers and contexts? Is it all forms of historical progressivism? Overly optimistic renditions? Materialist ones? Metaphysical ones? Progress becomes a cipher as the disparateness of concerns it stands in for makes it hard to see the quandary at hand, and what we're to draw out of their critiques. 
That said, they do have a center. But it isn't progress. It's the state. For each of these thinkers, the dream of progress countenances an overly activist and interventionist state. Schopenhauer denounces "state-led attempts to bring about the moral improvement of mankind [as] not only ineffectual, but dangerous" (21); for Leo Tolstoy, "[t]he individual's quest for moral improvement does not depend on the machinations of the state" (61), which he considered "an instrument of oppression" (62); Henry Adams, quite simply, sees "politics as a corrupt endeavor" (87). These aren't just critics of progress, then, but conservative and libertarian ones preoccupied with heavy-handed governments licensed by political idealism, which Slaboch acknowledges in the book's conclusion, and which seems hard to avoid, given their lamentations for the social disintegration precipitated by everything from irreligiosity, to rising greed, to women "reject[ing] their duties as wives and mothers" (84). This isn't a pessimism that aims to change the state, but one that runs from it.

Which raises the question: if we're looking for resources to guide political theory, as Slaboch describes his intention, why turn here? Why turn to thinkers that are marginal, not explicitly political, and far removed from our social, political, and intellectual contexts? None of these is in itself problematic: peripheral, nonpolitical, and distant figures often enrich and widen our political horizons. But it's not clear exactly how these ones do in ways that are novel or distinctive from their surrounding critics. Opposition to materialism and capitalism recalls Rousseau and Marx; Burke, Coleridge and Carlyle were scathing critics of unbounded political progressivism; Mill and Tocqueville castigated American democracy's deficits; Peirce, Dewey, and James rejected metaphysical conceptions of progress. How, then, do the pessimists get us to see the problem of progress differently, and still politically?

That last part - politically - is an important part of the question, and it's accentuated by the fact that, as we're reminded throughout, each of them was either apolitical, unpolitical, uninterested in politics, or ignored by those who are. Still worse, we're provided good reasons not to take their arguments seriously as Slaboch reveals the extent of their grounding in personal, rather than theoretical, concerns. He details Schopenhauer's vitriolic hatred of Hegel, for instance, and even cites a source treating his anti-historicism as derived from this personal animus (124, fn. 26). Nicholas I's resistance to progress straightforwardly seeks to curb criticism of his autocracy. Given that Henry Adams had every intention of entering the civil service until "the political post he had imagined for himself did not materialize... and he swiftly became a fierce critic of the very administration he had initially sought to join" (78), his indictment of democratic corruption comes off as the ressentiment-fueled screed of a Boston Brahmin fallen on hard times, rather than a conceptually-rich account of social decline. Also, while Slaboch's contextualism vividly renders their worlds, the book's biographical and psychologistic tendencies draw the focus away from the substance of their views

(c) 2018 Springer Nature Limited. 1470-8914 Contemporary Political Theory Vol. 18, S4, S243-S246 S245 
(Schopenhauer's critique of progress, for example, receives only 5 pages of a 25-page chapter). They are, finally, thinkers to approach with a certain level of circumspection, given their predilections to western chauvinism, authoritarianism, and apoliticism.

In the end, there's a stumbling block: it's hard to build a political theory out of unrelenting pessimism, which Slaboch recognizes in the admission that his figures - like most conservative critics of their ilk - are more likely to disrupt, rather than construct, political arrangements (113). But he wants them to do more to give us a political theory for our politically skeptical times. There are a lot of gestures toward the historical critique's contemporary utility, but it never quite gels: they sit side by side, parallel pessimisms, rather than one illuminating the other. To be sure, there are fascinating moments along the way: the WesternSlavophile debate, Henry Adams' appeal to entropy in theorizing social degradation, the distinction between outright pessimists and "cyclical" ones, and more. But while Slaboch wants to unsettle and resist the ideal of progress, what's being unsettled, and to what end, is less clear.

We might be heading for a splat. But what matters is precisely what we do while we're falling. These thinkers, Slaboch assures, are neither nihilists nor fatalists: each turned into himself - through art, philosophy, religion - when faced with the insuperable problems of political optimism. But this isn't actually a politics - it's a retreat from politics. It's less a political theory than a suggestion of its limits. What we're headed for is, of course, anyone's guess. But to want to do anything at all, from a political standpoint, rather than just wait for the splat, maybe we need to be able tell ourselves: so far, so good.

Inder S. Marwah McMaster University, Hamilton, ON L8S4L8, Canada marwahi@mcmaster.ca 